УДК 631.445.4:631.472.56] : 504

06.01.00 Агрономия

БАЛАНС ГУМУСА ПРИ ДЛИТЕЛЬНОМ ИС-
ПОЛЬЗОВАНИИ ЧЕРНОЗЕМА ВЫЩЕЛО-
ЧЕННОГО В РАВНИННОМ АГРОЛАНД-
ШАФТЕ В ЗАВИСИМОСТИ ОТ АГРОТЕХ-
НОЛОГИЙ ВОЗДЕЛЫВАНИЯ ПОЛЕВЫХ
КУЛЬТУР

Загорулько Александр Васильевич

д.с. - х. Н., профессор

Слюсарев Валерий Никифорович

д.с. - х. н., профессор

Кравцов Алексей Михайлович

д.с. - х. н., профессор

Василько Валентина Павловна

к.с. - х. н., профессор

Кубанский государственный аграрный университет, Краснодар, Россия

В статье, по итогам первой ротации севооборота, рассматриваются результаты исследований по влиянию технологий выращивания сельскохозяйственных культур различной степени интенсификации в звене полевого севооборота на изменение содержания в пахотном слое чернозема выщелоченного одного из основных показателей плодородия почвы - общего гумуса. Определение содержания общего гумуса в слое почвы $0-20$ см под озимой пшеницей, возделываемой после сахарной свеклы, кукурузы на зерно и подсолнечника колебалось по вариантам технологий от 3,02 до $3,72 \%$. Внесение органических удобрений под сахарную свеклу по вариантам изучаемых технологий, с целью моделирования уровней плодородия почвы, от 200 до 600 т/га и промежуточного их применения под эту культуру с нормой от 30 до 120 т/га способствовало, независимо от способа основной обработки почвы, увеличению содержания гумуса в почве от 3,38 до $3,65 \%$. В дальнейшем, по мере ротации культур в звене севооборота, в течение пяти лет наблюдалось падение содержания общего гумуса в пахотном слое по вариантам опыта от 0,09 до $0,21 \%$. Интенсификация технологий, повышение продуктивности культур в звене севооборота способствовало ежегодным потерям гумуса на $0,02-0,04 \%$. При применении же средней и высоких норм органических удобрений, содержание гумуса в пахотном слое не опускалось ниже первоначальных показателей уровня плодородия почвы и составляло $3,25-3,44 \%$. Это способствовало сохранению содержания общего гумуса, и следовательно, сохранению плодородия почвы по сравнению с вариантами, где органические удобрения не применялись. Установлено, что при выращивании
UDC 631.445.4:631.472.56] : 504

Agronomy

\section{THE BALANCE OF HUMUS WITH LONG- TERM USE OF BLACK LEACED SOIL IN THE PLAIN AGROLANDSCAPES DEPENDING ON AGROTECHNOLOGIES OF CULTIVATION OF FIELD CROPS}

\author{
Zagorulko Alexander Vasilyevich \\ Dr.Sci.Agr., professor \\ Sliusarev Valerii Nikiforovich \\ Dr.Sci.Agr., professor \\ Kravtsov Alexey Mikhailovich, \\ Dr.Sci.Agr., professor \\ Vasilko Valentina Pavlovna, \\ Cand.Agr.Sci., professor \\ Kuban State Agrarian University, Krasnodar, Russia
}

In the article, following the results of the first rotation of crop rotation, we consider results of researches on influence of technologies of cultivation of crops of various degree of intensification in a link of field crop rotation on change of the content in arable layer of the black leached soil of one of the main indicators of fertility of the soil - general humus. Determination of the total humus content in the soil layer $0-20 \mathrm{~cm}$ under winter wheat cultivated after sugar beet, corn for grain and sunflower ranged in terms of technology options from 3.02 to $3.72 \%$. Application of organic fertilizers for sugar beet on the variants of the studied technologies, in order to simulate soil fertility levels, from 200 to $600 \mathrm{t} / \mathrm{ha}$ and their intermediate application to this crop with a norm of 30 to 120 t/ha contributed, regardless of the method of basic tillage, to an increase in the humus content in the soil from 3.38 to $3.65 \%$. In the future, as crops rotate in the link of crop rotation, within five years there was a drop in the total humus content in the arable layer according to the variants of the experiment from 0.09 to $0.21 \%$. Intensification of technologies, increase of crop productivity in the link of crop rotation contributed to the annual loss of humus by $0.02-0.04 \%$. When applying the same average and high standards of organic fertilizers, humus content in the arable layer did not fall below the initial levels of soil fertility and was $3.25-3.44 \%$. This contributed to the maintenance of the total humus content, and therefore, the preservation of soil fertility compared with options where organic fertilizers were not used. It is established that at cultivation of field crops on technologies with application of the non - oval system of processing of the soil, the content of the General humus in a layer of the soil of 0-20 sm averaged $3,39 \%$. Application in the technologies of soil plowing 
полевых культур по технологиям с применением безотвальной системы обработки почвы, содержание общего гумуса в слое почвы 0 - 20 см составляло в среднем 3,39\%. Применение в технологиях отвальной обработки почвы снижало содержание гумуса в почве до 3,30\%, что уступало вариантам с безотвальной обработкой почвы на $0,09 \%$. При чередовании в севообороте поверхностной основной обработки почвы под колосовые и отвальной под пропашные (т.е рекомендуемой системы основной обработки почвы) терялось $0,012 \%$ гумуса в год, в то время как в технологиях с ежегодной отвальной с последствием глубокого рыхления обработкой почвы, дегумифакация составляла 0,027\% в год. В процессе исследований установлено, что выращивание сельскохозяйственных культур в звене севооборота по экологически допустимой технологии с применением средней нормы органических удобрений на фоне рекомендуемой для центральной зоны Краснодарского края системы основной обработки способствует большему сохранению гумуса в почве по сравнению с экстенсивной технологией (контролем) на $0,04 \%$ и на $0,06-0,07 \%$ при применении этой технологии на фоне отвальной и безотвальной обработок почвы

Ключевые слова: ЗЕРНОТРАВЯНО - ПРОПАШНОЙ СЕВООБОРОТ, ОЗИМАЯ ПШЕНИЦА, САХАРНАЯ СВЕКЛА, КУКУРУЗА, ПОДСОЛНЕЧНИК, ТЕХНОЛОГИИ, ОСНОВНАЯ ОБРАБОТКА ПОЧВЫ, БАЛАНС ГУМУСА

Doi: 10.21515/1990-4665-137-018 reduced humus content in the soil to $3.30 \%$, which was inferior to options with non-oval tillage by $0.09 \%$. With the alternation in the rotation surface of the main processing of the soil under cereals and moldboard tilled under (ie recommended system primary tillage) were lost to $0.012 \%$ of humus per year, while in the technologies with annual moldboard with side effects of deep loosening tillage, dehumification was of $0.027 \%$ per year. In the process of researches it is established that the cultivation of crops in crop rotation on environmentally acceptable technologies with application of the average rate of organic fertilizers on the background recommended for the Central zone of the Krasnodar region the main processing system contributes more to the preservation of humus in the soil compared to extensive technology (control) to $0.04 \%$ and $0.06-0.07$ percent when using this technology on the background of moldboard and subsurface tillage treatments of the soil

Keywords: GRAIN - GRASS ROW CROP ROTATION, WINTER WHEAT, SUGAR BEET, MAIZE, SUNFLOWER, TECHNOLOGY, MAIN PROCESSING OF THE SOIL, HUMUS BALANCE

\section{Введение.}

В условиях интенсивного использования черноземов Краснодарского края наблюдается снижение их естественного плодородия и, прежде всего, его основы - гумуса, содержание и запасы которого являются важным критерием оценки почвенного плодородия. Являясь основой плодородия почвы, гумус и его составные части - гумусовые вещества, не только сами участвуют в создании урожая растений, но и обеспечивают возможность для эффективного проявления других факторов и условий почвенного плодородия [3].

Гумус улучшает структуру почвы, создает благоприятный водновоздушный режим, способствует формированию оптимальных воднофизических, химических и физико-химических свойств, является источни- 
ком энергии для микробиологических процессов, в том числе, и процессов минерализации. Такие почвы обладают меньшей теплопроводностью, большей теплоемкостью и меньшей испаряемостью, что положительно сказывается как на почве, так и на росте и развитии растений. Гумусированные почвы обладают устойчивым пищевым режимом, буферностью к неблагоприятным почвенным факторам, снижают зависимость урожаев сельскохозяйственных культур от погодных условий, снимают отрицательное воздействие на растения высоких доз минеральных удобрений и пестицидов, повышают устойчивость земледелия в целом [3,5].

Проблема сохранения и повышения плодородия почв в сельскохозяйственном производстве является одной из актуальных. При прогрессирующей дегумифакации почв Краснодарского края, темпы которой составляют около 0,03 \% в год, особое значение приобретает разработка гумусосберегающих научно обоснованных технологий возделывания полевых культур, не только сохраняющих, но и повышающих содержание гумуса как интегрального показателя плодородия почвы. Данное положение по результатам исследований ряда ученых, прежде всего, касается пахотного слоя почвы, так как содержание гумуса в первую очередь характеризует эффективное плодородие черноземов, обеспечивает получение стабильных урожаев озимой пшеницы, кукурузы, подсолнечника и других полевых культур. [1,2,4,6]

В связи с этим цель наших исследований состояла в изучении влияния агротехнологий возделывания полевых культур, различной степени интенсивности, на изменение баланса общего гумуса чернозема выщелоченного в равнинном агроландшафте центральной зоны Краснодарского края.

\section{Материалы и методика исследований}

Исследования проводились в 1992-2004 гг. в стационарном многофакторном опыте на опытном поле Кубанского госагроуниверситета, рас- 
положенном в зоне неустойчивого увлажнения на выщелоченном слабогумусном сверхмощном легкоглинистом черноземе. Исследования проводились в 11-польном зернотравяно-пропашном севообороте.

В опыте изучались четыре фактора, в связи, с чем в его схеме принята специальная индексация (кодировка) вариантов, где первая цифра уровень плодородия почвы - А (0 -исходный, 1 - средний, 2 - повышенный, 3 - высокий), вторая - норма удобрения - В (0 - без удобрений, 1 минимальная, 2 - средняя, 3 - высокая), третья - система защиты растений - С (0 - без применения средств защиты, 1 - биологическая защита растений от вредителей и болезней, 2 - химическая защита от сорняков, 3 - химическая защита растений от вредителей, болезней и сорняков) и обработка почвы - Д (1 - безотвальная, 2 - рекомендуемая, 3 - отвальная + глубокое рыхление).

В целом по опыту изучалось 48 технологий возделывания каждой культуры.

При описании результатов исследований четыре технологии были приняты за базовые и условно названы: 000 - экстенсивная, 111 - беспестицидная, 222 - экологически допустимая, 333 - интенсивная.

Чтобы выйти на заданный уровень плодородия почвы по содержанию гумуса в выщелоченном черноземе при закладке стационарного опыта в 1992 году, на основе существующих нормативных показателей, путем последовательного внесения возрастающих доз полуперепревшего навоза КРС и суперфосфата, создали четыре модели уровней плодородия почвы (A): $\mathrm{A}_{1}-200$ кг/га $\mathrm{P}_{2} \mathrm{O}_{5}$ и 200 т/га подстилочного навоза; $\mathrm{A}_{2}$ - дозы удобрений удваивались; $\mathrm{A}_{3}$ - дозы удобрений утраивались; $\mathrm{A}_{0}$ - естественный фон плодородия.

Диапазоны норм минеральных удобрений (фактор В) под полевые культуры в изучаемом звене севооборота определялись на основе балансового метода с учетом планируемой урожайности, требуемого качества 
продукции, заданных темпов повышения плодородия, благоприятного состояния окружающей среды. Средняя норма удобрения $\left(\mathrm{B}_{2}\right)$ составлена на основе рекомендаций по применению минеральных удобрений в СевероКавказком регионе и соответствует их уровню в хозяйствах центральной зоны Краснодарского края. Минимальная норма $\left(\mathrm{B}_{2}\right)$ в два раза меньше и высокая $\left(\mathrm{B}_{3}\right)$ - в два раза больше, чем средняя норма минеральных удобрений.

Площадь делянки: общая - 4,2 м х 25,0 м = 105 м² ; учетная для кукурузы и подсолнечника - 2,8 м х 17,0 м = 47,6 м², для озимой пшеницы 2,0 м х 17,0 м = 34,0 м², сахарной свеклы 3,15 м х 17,0 м = 53,6 м². Повторность опыта - трехкратная. Расположение делянок - систематическое в двух блоках.

Наблюдения, учеты и анализы в опыте проводились по общепринятым методикам.

Изменение агрофизических и физико-химических свойств почвы определялось лабораторно - полевыми исследованиями по следующим показателям: общий гумус - по И. В. Тюрину (ГОСТ 26213-94); показатели ППК - сумма обменных оснований - по Каппену, гидролитическая кислотность - по Каппену - Гильковец, емкость катионного обмена, степень насыщенности основаниями - расчетным методом, обменная и активная кислотность - по методике ЦИНАУ (ГОСТ-26-484).

\section{Результаты исследования и обсуждение.}

Анализ почвенных образцов по содержанию общего гумуса в пахотном слое под озимой пшеницей, возделываемой после сахарной свеклы (1993 - 1995 гг.), кукурузы (1995 - 1997 гг.) и подсолнечника (19971999 гг.), варьировало в зависимости от технологий выращивания от 3,02 до $3,72 \%$ (табл.1). 
Таблица 1 - Изменение содержания общего гумуса в слое почвы 0-20 см под озимой пшеницей в зависимости от предшественника и технологий возделывания (1993-1999 гг.), \%

\begin{tabular}{|c|c|c|c|c|}
\hline \multirow{2}{*}{$\begin{array}{c}\text { Система основной об- } \\
\text { работки } \\
\text { почвы в } \\
\text { севообороте }\end{array}$} & \multirow{2}{*}{$\begin{array}{c}\text { Технология } \\
\text { возделывания }\end{array}$} & \multicolumn{3}{|c|}{ Предшественник } \\
\hline & & $\begin{array}{c}\text { сахарная } \\
\text { свекла }\end{array}$ & $\begin{array}{c}\text { кукуруза на } \\
\text { зерно }\end{array}$ & подсолнечник \\
\hline \multirow{5}{*}{$\begin{array}{c}\text { Безотвальная, } \\
\text { Д }_{1}\end{array}$} & Экстенсивная & 3,20 & 3,22 & 3,10 \\
\hline & Беспестицидная & 3,44 & 3,33 & 3,29 \\
\hline & $\begin{array}{l}\text { Экологически допусти- } \\
\text { мая }\end{array}$ & 3,57 & 3,37 & 3,45 \\
\hline & Интенсивная & 3,72 & 3,53 & 3,49 \\
\hline & Среднее & 3,48 & 3,36 & 3,33 \\
\hline \multirow{5}{*}{ Рекомендуемая, Д 2} & Экстенсивная (к) & 3,13 & 3,15 & 3,04 \\
\hline & Беспестицидная & 3,35 & 3,37 & 3,24 \\
\hline & $\begin{array}{l}\text { Экологически допусти- } \\
\text { мая }\end{array}$ & 3,47 & 3,39 & 3,42 \\
\hline & Интенсивная & 3,63 & 3,56 & 3,46 \\
\hline & Среднее & 3,39 & 3,36 & 3,29 \\
\hline \multirow{5}{*}{$\begin{array}{c}\text { Отвальная с последей- } \\
\text { ствием глубокого рых- } \\
\text { ления до } 70 \text { см, } \\
\text { Д }_{3}\end{array}$} & Экстенсивная & 3,09 & 3,08 & 3,02 \\
\hline & Беспестицидная & 3,36 & 3,23 & 3,21 \\
\hline & $\begin{array}{l}\text { Экологически допусти- } \\
\text { мая }\end{array}$ & 3,47 & 3,34 & 3,36 \\
\hline & Интенсивная & 3,61 & 3,44 & 3,37 \\
\hline & Среднее & 3,38 & 3,26 & 3,24 \\
\hline
\end{tabular}

Наименьшее содержание общего гумуса в почве под озимой пшеницей после сахарной свеклы наблюдалось на вариантах с экстенсивной технологией: от 3,20 \%, при применении в звене севооборота безотвальной системы основной обработки, до 3,09 \% с ежегодной отвальной на фоне последействия глубокого рыхления.

На вариантах возделывания озимой пшеницы по беспестицидной, экологически допустимой и интенсивной технологиям, в которых одним из изучаемых факторов был различный уровень плодородия почвы , содержание общего гумуса по соответствующим технологиям на фоне безотвальной обработки почвы составляло 3,44 - 3,72\%, рекомендуемой - 3,35 3,63\% и ежегодной отвальной с последействием глубокого рыхления - 3,36 - 3,61\%. Такое содержание общего гумуса в пахотном слое на данных ва- 
риантах превышало в 1,07 -1,17 раза его наличие в почве под озимой пшеницей, возделываемой по экстенсивным технологиям.

Установлено, что при моделировании уровней плодородия почвы от среднего до высокого с внесением органических удобрений по вариантам изучаемых технологий от 200 до 600 т/га и промежуточного их применения под сахарную свеклу с нормой от 30 до 120 т/га содержание общего гумуса в почве, независимо от способа основной обработки почвы озимой пшеницы, повышалось от 3,38 до 3,65 \% (табл. 2).

Таблица 2 - Влияние удобрений и предшественников на содержание общего гумуса в слое почвы 0-20 см под озимой пшеницей,\%, (1994-1999 гг.)

\begin{tabular}{|c|c|c|c|c|}
\hline \multirow{2}{*}{ Вариант } & \multicolumn{2}{|c|}{ Предшественник } & \multicolumn{2}{|c|}{ Изменение общего гумуса } \\
\cline { 2 - 5 } & сахарная свекла & подсолнечник & за 5 лет \pm & расчете за 1 год \\
\hline $\begin{array}{c}\text { Без удобрения, } \\
\text { естественное } \\
\text { плодородие }\end{array}$ & 3,14 & 3,05 & $-0,09$ & 0,02 \\
\hline $\begin{array}{c}\mathrm{N}_{39} \mathrm{P}_{32} \mathrm{~K}_{20}+ \\
\text { наво3 } 4,5 \text { т/га, } \\
\text { среднее плодо- } \\
\text { родие }\end{array}$ & 3,38 & 3,25 & $-0,13$ & 0,03 \\
\hline $\begin{array}{c}\mathrm{N}_{78} \mathrm{P}_{64} \mathrm{~K}_{39}+ \\
\text { наво3 } 9,0 \text { т/га, } \\
\text { повышенное } \\
\text { плодородие }\end{array}$ & 3,50 & 3,41 & $-0,09$ & 0,02 \\
\hline $\begin{array}{c}\mathrm{N}_{156} \mathrm{P}_{127} \mathrm{~K}_{78}+ \\
\text { навоз } 18,0 \text { т/га } \\
\text { высокое плодо- } \\
\text { родие }\end{array}$ & 3,65 & 3,44 & $-0,21$ & 0,04 \\
\hline
\end{tabular}

Прирост общего гумуса под озимой пшеницей после сахарной свеклы в пахотном горизонте на второй год после применения полупревшего навоза составил 0,24 - 0,36 и 0,51\%.То есть, с внесением все возрастающих доз органических удобрений, содержание общего гумуса незначительно повышалось.

Дальнейшие наблюдения за динамикой содержания общего гумуса с 1995 по 1999 гг. показали, что в процессе ротации культур в звене севооборота кукуруза на зерно - озимая пшеница - подсолнечник - озимая пшеница наблюдалось снижение его содержания в пахотном слое по вари- 
антам опыта на $0,09-0,21 \%$ (табл. 2). Однако закономерности в большем содержании общего гумуса с увеличением нормы удобрения по вариантам опыта сохранялись. Так, за ротацию культур в звене севооборота, содержание общего гумуса после озимой пшеницы, возделываемой по подсолнечнику, составило в среднем, независимо от способа основной обработки, на варианте без удобрений 3,05\%. Под влиянием внесения перед закладкой опытов 200, 400 и 600 т/га органических удобрений, содержание гумуса достигло 3,25, 3,41 и 3,44\% соответственно. При этом по мере интенсификации технологий и повышения продуктивности культур в звене севооборота, ежегодные потери общего гумуса возрастали с 0,02\% на варианте без удобрений до $0,04 \%$ на варианте с высокой нормой удобрений. Однако, на вариантах с применением больших доз органических удобрений, содержание гумуса в пахотном слое, с момента закладки многолетнего стационара и до 1999 года, не опускалось ниже запланированных параметров уровней плодородия почвы. То есть, применение навоза с суммарной нормой от 250 до 800 т/га в первой половине ротации севооборота способствовало, прежде всего, сохранению содержания общего гумуса, и, следовательно, сохранению плодородия почвы по сравнению с вариантами, где органические удобрения не применялись.

Следует отметить, что сохранению общего гумуса в пахотном слое почвы на вариантах с внесением больших норм органических удобрений способствовало наличие и последующее разложение более мощной, чем на вариантах без применения навоза, массы корневых и пожнивных остатков, остающихся на поле после уборки изучаемых культур. Изменение содержания общего гумуса происходило и под воздействием применяемых в севообороте систем основной обработки почвы. Так, если при возделывании культур в изучаемом звене севооборота по технологиям с применением безотвальной системы основной обработки почвы, содержание общего гумуса, в среднем составляло $3,39 \%$, то на рекомендуемой и отвальной об- 
работках, гумуса уже терялось на 0,04 и $0,09 \%$ больше с содержанием его, соответственно, 3,35 и 3,30\% (табл. 3).

Таблица 3 - Результаты дисперсионного анализа содержания общего гумуса в почве под озимой пшеницей (\%) в зависимости от предшественника и технологий возделывания (1993 - 1999 гг.)

\begin{tabular}{|c|c|c|c|c|c|c|c|}
\hline \multirow{2}{*}{$\begin{array}{c}\text { Система основ- } \\
\text { ной обработки } \\
\text { почвы в севооб- } \\
\text { ороте, Д }\end{array}$} & \multirow[b]{2}{*}{$\begin{array}{l}\text { Предше- } \\
\text { ственник }\end{array}$} & \multirow[b]{2}{*}{$\begin{array}{c}\text { Индекс } \\
\text { технологий, T }\end{array}$} & \multicolumn{4}{|c|}{ Среднее по } & \multirow{2}{*}{$\begin{array}{c}\text { Эффект от эле- } \\
\text { ментов техноло- } \\
\text { гии (ДКТ) }\end{array}$} \\
\hline & & & Д & K & $\mathrm{T}$ & вариантам & \\
\hline 1 & 2 & 3 & 4 & 5 & 6 & 7 & 8 \\
\hline \multirow{12}{*}{$\begin{array}{c}\text { Безотвальная, } \\
\text { Д }_{1}\end{array}$} & \multirow{4}{*}{$\begin{array}{c}\text { Сахарная } \\
\text { свекла }\end{array}$} & 000 & \multirow{12}{*}{3,39} & \multirow{4}{*}{3,42} & & 3,20 & $-0,014$ \\
\hline & & 111 & & & & 3,44 & $-0,001$ \\
\hline & & 222 & & & & 3,57 & 0,011 \\
\hline & & 333 & & & & 3,72 & 0,004 \\
\hline & \multirow{4}{*}{$\begin{array}{l}\text { Кукуруза } \\
\text { на зерно }\end{array}$} & 000 & & \multirow{4}{*}{3,34} & & 3,22 & 0,027 \\
\hline & & 111 & & & & 3,33 & $-0,003$ \\
\hline & & 222 & & & & 3,37 & $-0,016$ \\
\hline & & 333 & & & & 3,53 & $-0,009$ \\
\hline & \multirow{4}{*}{$\begin{array}{l}\text { Подсол- } \\
\text { нечник }\end{array}$} & 000 & & \multirow{4}{*}{3,29} & & 3,10 & $-0,014$ \\
\hline & & 111 & & & & 3,29 & 0,004 \\
\hline & & 222 & & & & 3,45 & 0,004 \\
\hline & & 333 & & & & 3,49 & 0,005 \\
\hline \multirow{12}{*}{$\begin{array}{c}\text { Рекомендуемая, } \\
\text { Д }_{2}\end{array}$} & \multirow{4}{*}{$\begin{array}{c}\text { Сахарная } \\
\text { свекла }\end{array}$} & 000 & \multirow{12}{*}{3,35} & & & 3,13 & 0,027 \\
\hline & & 111 & & & & 3,35 & $-0,012$ \\
\hline & & 222 & & & & 3,48 & $-0,004$ \\
\hline & & 333 & & & & 3,63 & $-0,011$ \\
\hline & \multirow{4}{*}{$\begin{array}{l}\text { Кукуруза } \\
\text { на зерно }\end{array}$} & 000 & & & & 3,15 & $-0,025$ \\
\hline & & 111 & & & & 3,37 & 0,024 \\
\hline & & 222 & & & & 3,39 & $-0,006$ \\
\hline & & 333 & & & & 3,56 & $-0,007$ \\
\hline & \multirow{4}{*}{$\begin{array}{l}\text { Подсол- } \\
\text { нечник }\end{array}$} & 000 & & & & 3,04 & $-0,002$ \\
\hline & & 111 & & & & 3,24 & $-0,012$ \\
\hline & & 222 & & & & 3,42 & 0,010 \\
\hline & & 333 & & & & 3,46 & 0,005 \\
\hline
\end{tabular}


Продолжение таблицы 3

\begin{tabular}{|c|c|c|c|c|c|c|c|}
\hline \multirow{12}{*}{$\begin{array}{c}\text { Отвальная с по- } \\
\text { следействием } \\
\text { глубокого рых- } \\
\text { ления до } 70 \text { см, } \\
\text { Д }_{3}\end{array}$} & \multirow{4}{*}{$\begin{array}{c}\text { Сахарная } \\
\text { свекла }\end{array}$} & 000 & \multirow{12}{*}{3,30} & & & 3,09 & $-0,014$ \\
\hline & & 111 & & & & 3,36 & 0,013 \\
\hline & & 222 & & & & 3,47 & $-0,008$ \\
\hline & & 333 & & & & 3,61 & 0,008 \\
\hline & \multirow{4}{*}{$\begin{array}{l}\text { Кукуруза } \\
\text { на зерно }\end{array}$} & 000 & & & & 3,08 & $-0,003$ \\
\hline & & 111 & & & & 3,23 & $-0,022$ \\
\hline & & 222 & & & & 3,34 & 0,022 \\
\hline & & 333 & & & & 3,44 & 0,002 \\
\hline & \multirow{4}{*}{$\begin{array}{l}\text { Подсол- } \\
\text { нечник }\end{array}$} & 000 & & & 3,11 & 3,02 & 0,016 \\
\hline & & 111 & & & 3,32 & 3,21 & 0,008 \\
\hline & & 222 & & & 3,43 & 3,36 & $-0,015$ \\
\hline & & 333 & & & 3,54 & 3,37 & $-0,010$ \\
\hline & \multicolumn{2}{|l|}{$\mathrm{HCP}_{0,5} \%$} & 0,08 & 0,08 & 0,09 & 0,27 & 0,27 \\
\hline
\end{tabular}

Примечание - Д - способ основной обработки почвы; К - культура; $\mathrm{T}$-технология возделывания.

Снижение содержания общего гумуса на $0,09 \%$ на вариантах с ежегодной отвальной обработкой на фоне последействия глубокого рыхления почвы по сравнению с безотвальной является существенным по материалам дисперсионного анализа $\left(\mathrm{HCP}_{0,5}=0,08 \%\right)$. Потери же гумуса в почве на 0,04\% при применении в технологиях рекомендуемой системы основной обработки почвы являлись не существенными, что позволяет утверждать о наблюдающейся тенденции в снижении плодородия почвы.

Установлено, что наиболее стабильное содержание гумуса, при последовательном его снижении пахотном слое почвы по мере ротации культур в звене севооборота в 1999 году наблюдалось при их возделывании по экологически допустимой технологии на фоне всех трех изучаемых систем основной обработки почвы. Здесь потери гумуса, по сравнению с исходным его содержанием, составили $0,05 \%$, в сравнении с $0,11-0,12 \%$ при безотвальной и отвальной обработках почвы.

При возделывании культур по экологически допустимой технологии на фоне рекомендуемой основной обработки почвы, то есть с чередо- 
ванием поверхностной под колосовые и отвальной обработки почвы под пропашные, терялось лишь 0,012\% гумуса в год, тогда как на вариантах этой технологии с безотвальной и ежегодной отвальной с последействием глубокого рыхления обработками, дегумифакация почвы составляла 0,030 и $0,027 \%$ в год. То есть, применение рекомендуемой системы основной обработки почвы при возделывании культур в звене севооборота по экологически допустимой технологии способствовало большему сохранению гумуса по сравнению с контролем на 0,04 \% и на 0,06 - 0,07 \% при применении этой технологии на фоне отвальной и безотвальной обработок почвы.

Возделывание культур по интенсивной технологии с ежегодной отвальной обработкой почвы способствовало наибольшим темпам разрушения гумуса. Ежегодно здесь терялось до 0,06\% органического вещества, что больше в 3 раза по сравнению с контролем и в 5 раз, чем при возделывании культур по экологически допустимой технологии на фоне рекомендуемой обработки почвы. То есть, по мере интенсификации систем основной обработки почвы в данном звене севооборота, содержание общего гумуса в пахотном слое снижалось. Наиболее высокое содержание общего гумуса в пахотном слое почвы обеспечивалось применением безотвальной системы основной обработки почвы. Данной системе, по своему действию на процесс дегумифакации, практически была равнозначна рекомендуемая система обработки, при использовании которой наблюдалось лишь тенденция в снижении содержания гумуса. Возделывание культур по технологиям с ежегодной отвальной на фоне последействия глубокого рыхления способствовало существенным потерям гумуса.

Процесс накопления гумуса в значительной степени связан с урожайностью сельскохозяйственных культур. На основании урожайных данных был рассчитан баланс гумуса за период с 1992 по 2004 годы на черноземе выщелоченном агроэкологического мониторинга. Расчет основан на 
выносе урожаем азота, извлеченного из органического вещества почвы, потерь при минерализации и накопления в результате разложения растительных остатков (табл.4).

Таблица 4 - Баланс гумуса в черноземе выщелоченном в системе агроэкологического мониторинга (1992 - 2004 гг.).

\begin{tabular}{|c|c|c|c|c|c|}
\hline $\begin{array}{c}\text { Уровень пло- } \\
\text { дородия } \\
\text { почвы }\end{array}$ & $\begin{array}{c}\text { Индекс } \\
\text { варианта опыта }\end{array}$ & $\begin{array}{c}\text { Минерализация } \\
\text { гумуса, ц/га }\end{array}$ & $\begin{array}{c}\text { Накопление гу- } \\
\text { муса, ц/га }\end{array}$ & $\begin{array}{c}\text { Баланс } \\
\text { гумуса, ц/га }\end{array}$ & $\begin{array}{c}\text { Среднее } \\
\text { значение } \\
\text { баланса } \\
\text { гумуса, } \\
\text { ц/га }\end{array}$ \\
\hline \multirow{3}{*}{$\mathrm{A}_{0}$} & $000\left(Д_{1}\right)$ & 180,7 & 159,9 & $-20,8$ & \multirow{3}{*}{$-19,6$} \\
\hline & $000\left(Д_{2}\right)$ & 177,5 & 156,5 & $-21,0$ & \\
\hline & $000\left(Д_{3}\right)$ & 178,7 & 161,7 & $-17,0$ & \\
\hline \multirow{3}{*}{$\mathrm{A}_{1}$} & 111(Д $)$ & 202,9 & 177,4 & $-25,5$ & \multirow{3}{*}{$-26,4$} \\
\hline & $111\left(Д_{2}\right)$ & 212,9 & 184,2 & $-28,7$ & \\
\hline & $111\left(Д_{3}\right)$ & 214,6 & 189,5 & $-25,1$ & \\
\hline \multirow{3}{*}{$\mathrm{A}_{2}$} & $222\left(Д_{1}\right)$ & 230,7 & 204,5 & $-26,2$ & \multirow{3}{*}{$-27,2$} \\
\hline & $222\left(Д_{2}\right)$ & 234,9 & 208,5 & $-28,7$ & \\
\hline & $222\left(Д_{3}\right)$ & 239,1 & 2012,5 & $-26,6$ & \\
\hline \multirow{3}{*}{$\mathrm{A}_{3}$} & $333\left(Д_{1}\right)$ & 244,0 & 221,3 & $-22,7$ & \multirow{3}{*}{$-21,0$} \\
\hline & $333\left(Д_{2}\right)$ & 245,2 & 222,7 & $-22,5$ & \\
\hline & $333\left(Д_{2}\right)$ & 248,8 & 231,0 & $-17,8$ & \\
\hline \multirow{3}{*}{$\mathrm{A}_{0}$} & $002\left(Д_{2}\right)$ & 185,1 & 163,8 & $-21,3$ & \multirow{3}{*}{$-22,2$} \\
\hline & $020\left(Д_{2}\right)$ & 219,8 & 203,4 & $-16,4$ & \\
\hline & $022\left(Д_{2}\right)$ & 232,2 & 203,2 & $-29,0$ & \\
\hline \multirow{3}{*}{$\mathrm{A}_{2}$} & $200\left(Д_{2}\right)$ & 200,2 & 175,1 & $-25,1$ & \multirow{3}{*}{$-25,2$} \\
\hline & $202\left(Д_{2}\right)$ & 208,0 & 184,3 & $-23,3$ & \\
\hline & $220\left(Д_{2}\right)$ & 222,1 & 195,0 & $-27,1$ & \\
\hline
\end{tabular}

Примечание: $\mathrm{A}_{0}$ - без органических удобрений; $\mathrm{A}_{1}-250$ т/га навоз за ротацию; $\mathrm{A}_{2}-500$ т/га навоза за ротацию; $\mathrm{A}_{3}-800$ т/га навоза за ротацию.

Расчет баланса гумуса проводился за ротацию как разность между его увеличением за счет пожнивно - корневых остатков, органических удобрений и потерями при минерализации. Исходным материалом являются данные урожайности сельскохозяйственных культур севооборота. Ми- 
нерализация гумуса ориентировочно была определена по расходу почвенного азота на формирование урожая. При этом было установлено, что в отсутствии внесения органических удобрений, баланс гумуса в почве был отрицательный.

Применение минеральных удобрений на фоне естественного $\left(\mathrm{A}_{0}\right)$ и повышенного $\left(\mathrm{A}_{2}\right)$ плодородия почвы существенно на величине баланса гумуса не сказалось.

В таблице 5 даны расчеты баланса гумуса с учетом вносимого навоза, который успешно компенсировал его потери. Отрицательный баланс гумуса наблюдался только на неудобренном варианте. Для того чтобы компенсировать дефицит гумуса в 19,6 - 22,2 ц/га, необходимо внесение 30,2 - 34,2 т/га навоза за 11 - летний цикл зернотравяно - пропашного севооборота.

Таблица 5 - Расчет баланса гумуса с учетом вносимых органических удобрений в черноземе выщелоченном агроэкологического мониторинга (1992 - 2004 гг.)

\begin{tabular}{|c|c|c|c|c|}
\hline $\begin{array}{c}\text { Уровень } \\
\text { плодородия } \\
\text { почвы }\end{array}$ & $\begin{array}{c}\text { Баланс } \\
\text { гумуса, ц/га }\end{array}$ & $\begin{array}{c}\text { Внесено навоза, } \\
\text { т/га }\end{array}$ & $\begin{array}{c}\text { Пересчет навоза } \\
\text { в гумус, ц/га }\end{array}$ & $\begin{array}{c}\text { Общий } \\
\text { баланс } \\
\text { гумуса, ц/га }\end{array}$ \\
\hline \multirow{2}{*}{$\mathrm{A}_{0}$} & $-19,6$ & 0 & 0 & $-19,6$ \\
\cline { 2 - 5 } & $-22,2$ & 0 & 0 & $-22,2$ \\
\hline $\mathrm{A}_{1}$ & $-26,4$ & 250 & 162,5 & $+136,1$ \\
\hline $\mathrm{A}_{2}$ & $-27,2$ & 500 & 325,0 & $+297,8$ \\
\hline $\mathrm{A}_{3}$ & $-25,2$ & 500 & 325 & $+299,2$ \\
\hline
\end{tabular}

\section{Выводы.}

Выращивание полевых культур в звене севооборота сахарная свеклаозимая пшеница - кукуруза на зерно - озимая пшеница - подсолнечник озимая пшеница по технологиям с применением органических удобрений с 
нормой от 200 - 600 т/га на фоне безотвальной, отвальной и рекомендуемой для центральной зоны Краснодарского края системы основной обработки почвы, способствовало сохранению гумуса в пахотном слое почве 0 - 20 см. При этом выделялась экологически допустимая технология, где применение средней нормы органических удобрений на фоне рекомендуемой обработки почвы способствовало большему сохранению гумуса на 0,04\% по сравнению с контролем и на 0,06 - 0,07 \% при применении этой технологии на фоне отвальной и безотвальной обработок почвы.

\section{Список литературы.}

1. Ачканов А.Я. Мониторинг гумусного состояния почв/ А.Я. Ачканов, В.П. Василько, А.В. Загорулько и др.// Агроэкологический мониторинг в земледелии Краснодарского края. - Вып. 2. - Краснодар: Агропромполиграфист, 2002. - С.23 - 30.

2. Загорулько А.В. Технологии возделывания полевых культур и их воздействие на плодородие почвы в звене зернотравяно - пропашного севооборота/А.В. Загорулько, В.Г. Кравченко// Совершенствование систем земледелия в различных агроландшафтах Краснодарского края: сб. доклад. науч. - практ. конф. 18 - 20 марта 2004 г. - Краснодар, 2004. - С.175 - 178.

3. Загорулько А.В. Влияние технологий возделывания полевых культур на изменение плодородия почвы в звене зернотравяно - пропашного севооборота/ A.В. Загорулько, В.Н. Слюсарев, В.Г. Живчиков и др.// Тр./КубГАУ: сб. науч. тр.- Вып. 425 (453). - Краснодар, 2005. - С. 172 - 192.

4. Кравцов А.М. Агроэкологические основы технологии выращивания сахарной свеклы и озимой пшеницы в зернотравяно - пропашном севообороте на выщелоченном черноземе Западного Предкавказья/ А.М. Кравцов// Дис..д-ра с.-х. наук. - Краснодар, 2000. -515 c.

5. Трубилин И.Т. Состояние плодородия пахотных земель Кубани и пути его повышения/ И.Т. Трубилин, В.П. Василько, Н.Г. Малюга, Ю.А. Штомпель и др.// Тр./ КубГАУ: сб. науч.тр. - Вып. 425 (453). - Краснодар, 2005. - С. 103 - 124.

6. Штомпель Ю.А. Мониторинг гумусного состояния черноземов в условиях интенсивного сельскохозяйственного использования в агроландшафтах Кубани/ Ю.А. Штомпель//Тр. КубГАУ.: сб. науч.тр.- Вып. 425 (453). - Краснодар, 2005. - С. 124 127.

\section{References.}

1. Achkanov A.Ja. Monitoring gumusnogo sostojanija pochv/ A.Ja. Achkanov, V.P. Va-sil'ko, A.V. Zagorul'ko i dr.// Agrojekologicheskij monitoring v zemledelii Krasnodarskogo kraja. - Vyp. 2. - Krasnodar: Agroprompoligrafist, 2002. - S.23 - 30.

2. Zagorul'ko A.V. Tehnologii vozdelyvanija polevyh kul'tur $i$ ih vozdejstvie na plodorodie pochvy v zvene zernotravjano - propashnogo sevooborota/A.V. Zagorul'ko, V.G. Kravchenko// Sovershenstvovanie sistem zemledelija v razlichnyh agrolandshaftah Krasno- 
darskogo kraja: sb. doklad. nauch. - prakt. konf. 18 - 20 marta 2004 g. - Krasno-dar, 2004. S.175 - 178 .

3. Zagorul'ko A.V. Vlijanie tehnologij vozdelyvanija polevyh kul'tur na izme-nenie plodorodija pochvy v zvene zernotravjano - propashnogo sevooborota/ A.V. Za-gorul'ko, V.N. Sljusarev, V.G. Zhivchikov i dr.// Tr./KubGAU: sb. nauch. tr.- Vyp. 425 (453). - Krasnodar, 2005. - S. $172-192$.

4. Kravcov A.M. Agrojekologicheskie osnovy tehnologii vyrashhivanija saharnoj svekly i ozimoj pshenicy v zernotravjano - propashnom sevooborote na vyshhelochennom chernozeme Zapadnogo Predkavkaz'ja/ A.M. Kravcov// Dis..d-ra s.-h. nauk. - Krasnodar, 2000. $-515 \mathrm{~s}$.

5. Trubilin I.T. Sostojanie plodorodija pahotnyh zemel' Kubani i puti ego po-vyshenija/ I.T. Trubilin, V.P. Vasil'ko, N.G. Maljuga, Ju.A. Shtompel' i dr.// Tr./ KubGAU: sb. nauch.tr. - Vyp. 425 (453). - Krasnodar, 2005. - S. 103 - 124.

6. Shtompel' Ju.A. Monitoring gumusnogo sostojanija chernozemov v uslovijah intensivnogo sel'skohozjajstvennogo ispol'zovanija v agrolandshaftah Kubani/ Ju.A. Shtompel'//Tr. KubGAU.: sb. nauch.tr.- Vyp. 425 (453). - Krasnodar, 2005. - S. 124 - 127. 